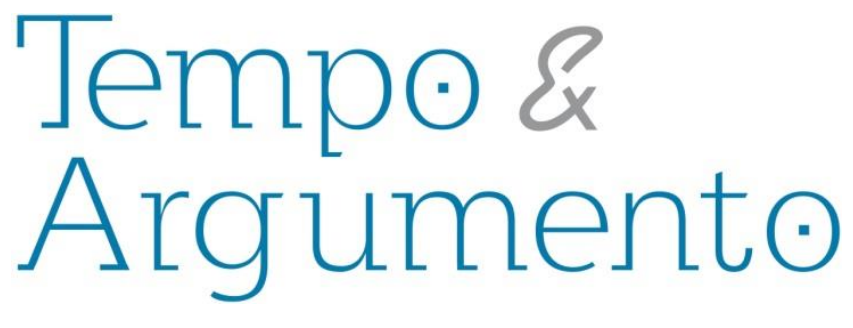

\title{
A pena de morte na Ditadura Civil-Militar brasileira: uma análise processual
}

\begin{abstract}
Resumo
O presente artigo trata a respeito da pena de morte durante a ditadura militar brasileira a partir de dois casos julgados pela justiça militar, durante esse período, em que os réus foram condenados à morte por sua participação no assassinato de um tenente do exército durante a guerrilha no Vale do Ribeira. Os acusados, membros da Vanguarda Popular Revolucionária, foram presos, torturados e julgados pela justiça militar, sendo condenados à morte. Tal sentença acabou sendo revertida posteriormente, porém trata-se de casos emblemáticos em que é possível verificar a parcialidade dos tribunais militares e o tratamento dado às pessoas tidas como subversivas pelo regime.
\end{abstract}

Palavras-chave: Brasil - História - 1964-1985. Ditadura e Ditadores - Brasil. Pena de Morte. Brasil - Segurança Nacional.

\section{Felipe Cittolin Abal}

Doutor em História pela Universidade de Passo Fundo (UPF). Professor da Universidade de Passo Fundo (UPF). Passo Fundo - RS - Brasil felipe.c.abal@hotmail.com

\section{Ana Luiza Setti Reckziegel}

Doutora em História Ibero Americana pela Pontifícia Universidade Católica do Rio Grande do Sul (PUCRS). Professora da Universidade de Passo Fundo (UPF).

Passo Fundo - RS - Brasil analuiza@upf.br

\section{Para citar este artigo:}

ABAL, Felipe Cittolin; RECKZIEGEL, Ana Luiza Setti. A pena de morte na Ditadura CivilMilitar brasileira: uma análise processual. Tempo e Argumento, Florianópolis, v. 10, n. 25, p. 238 - 357, jul./set. 2018. 


\title{
The death penalty in the brazilian Civil-Military \\ Dictatorship: a judicial process analysis
}

\begin{abstract}
This article deals with the death penalty during the Brazilian military dictatorship analyzing two cases judged by military courts during the Brazilian military dictatorship in which the defendants were sentenced to death for their participation in the murder of an army lieutenant during the guerrilla warfare in the Ribeira Valley. The defendants, members of the Revolutionary Popular Vanguard, were arrested, tortured and tried by the military justice system and sentenced to death. This sentence was subsequently reversed, but they are emblematic cases in which it is possible to verify the partiality of the military courts and the treatment given to the people considered as subversive by the military regime.
\end{abstract}

Keywords: Brazil - History - 1964-1985. Dictatorship and Dictators - Brazil. Death Penalty. Brazil - National

Security .

\section{Considerações iniciais}

A ditadura militar no Brasil é um acontecimento muito bem explorado pela historiografia brasileira. Não é uma novidade tratar a respeito de agressões, torturas e mortes ocorridas durante o período. Também não são inéditas reflexões sobre o caráter repressivo e parcial da justiça militar durante esse regime. O presente artigo, porém, busca analisar um caso emblemático ocorrido durante a ditadura militar brasileira: a condenação à morte pela justiça militar de dois guerrilheiros, membros da Vanguarda Popular Revolucionária. 
O regime militar possuiu como característica marcante o fato de tentar, na medida do possível, se encobrir por uma máscara de legitimidade e legalidade, realizando alterações legislativas, criando documentos jurídicos (a exemplo dos Atos Institucionais $\mathrm{Al}$ ) e alterando as competências judiciais, atraindo para a justiça militar diversas causas que seriam julgadas com a menor imparcialidade possível (PEREIRA, 2010). Seguindo essa constatação, podem ser denotados dois pontos de interesse. Primeiramente, a pouca discussão a respeito dos mecanismos legais surgidos durante a ditadura militar, especialmente o Al-14, que permitia a execução dos condenados pelos chamados crimes contra a segurança nacional (destaque-se os excelentes trabalhos de SILVA, 2014, e LEMOS, 2004). Em segundo lugar, também são raramente expostos os casos dos quatro brasileiros condenados à morte tendo por base esta legislação.

Assim, este estudo pretende expor os casos de Ariston Lucena e Diógenes Sobrosa de Souza, condenados à morte, e analisar as decisões no âmbito da justiça militar e, posteriormente, do Supremo Tribunal Federal, expondo os argumentos da defesa, da acusação e o conteúdo das próprias decisões.

Inicialmente será realizada uma reflexão a respeito das organizações de resistência à ditadura militar com foco na Vanguarda Popular Revolucionária, da qual os réus faziam parte, com o intuito de compreender o contexto em que os acusados cometeram os crimes pelos quais foram julgados e também comparar esses fatos com o exposto no decorrer do processo.

Posteriormente, será possível analisar os casos de Ariston Lucena e Diógenes Sobrosa de Souza, partindo do início dos processos, utilizando como fonte de pesquisa principal a documentação existente e obtida junto ao Projeto Brasil: Nunca Mais, perpassando pelas peças de defesa e acusação e chegando às decisões judiciais.

Através do presente artigo pretende-se, portanto, trazer à luz os casos estudados e também analisá-los como forma de compreender o funcionamento da Justiça Militar e o tratamento dado aos réus nessa instância, tendo tais condenações como paradigmas, complementando os referidos trabalhos que focaram nos temas do Al-14 e da Justiça Militar no Brasil e, ainda, demonstrar o uso deste ramo do poder judiciário e da própria pena de morte como um instrumento de ameaça por parte do governo ditatorial militar. 


\section{Vanguarda Popular Revolucionária: a resistência no Vale do Ribeira}

Passados quatro anos do golpe que alçou os militares ao poder no Brasil, diversas organizações de esquerda operavam no país com o intuito de resistir à ditadura, variando entre si em relação aos métodos, objetivos e inspirações. Para fins deste estudo, cumpre traçar algumas linhas a respeito da Vanguarda Popular Revolucionária (VPR), organização da qual os réus, alvos dos processos analisados, faziam parte, até as ações no Vale do Ribeira.

A VPR começou a atuar no segundo semestre de 1968 em busca de meios para iniciar a resistência armada no país. O maior acréscimo aos quadros da organização foi realizado no mesmo ano: o capitão do Exército Carlos Lamarca, comandante do $4^{\circ}$ Regimento de Infantaria em Quitaúna. O plano para a saída de Lamarca do exército era audacioso e envolvia um ataque em grande escala. Em 26 de janeiro, o capitão e seus companheiros roubariam o arsenal do quartel em um caminhão pintado com o verdeescuro típico dos veículos militares. Os membros da VPR bombardeariam o palácio dos Bandeirantes, o QG do II Exército e a Academia de Polícia, enquanto um comando tomaria a torre de controle do Campo de Marte impedindo as comunicações aéreas da cidade (GASPARI, 2014, p. 119).

Faltando três dias para colocar o plano em prática, os guerrilheiros não podiam imaginar que sua estratégia seria destruída por uma criança. Enquanto era terminada a pintura do caminhão na cidade de Ibiti, um menino que morava nas redondezas aproximou-se dos pintores que o escorraçaram do local. Os pais chamaram a polícia e quatro membros da VPR foram presos. Temerosos com as informações que poderiam ser obtidas, era necessário que o plano fosse abortado e uma nova estratégia foi improvisada. Lamarca desertou no dia seguinte junto dos militantes de sua célula, levando consigo uma Kombi, 63 FAL (fuzil automático leve) e três submetralhadoras (GASPARI, 2014, p. 120-123). Mesmo com o fracasso da ação, o plano de Lamarca de estabelecer um foco de guerrilha rural não foi deixado de lado.

Com isso, 1969 foi um ano de reveses para as organizações de resistência armada. A prisão dos quatro membros da VPR desarticulou o grupo. Era necessário pensar em 
resolução para a fusão dos grupos em uma nova entidade, denominada Vanguarda Armada Revolucionária - Palmares (VAR-Palmares). A primeira ação da nova organização foi a expropriação do cofre da residência de Ana Capriglione, amante do ex-governador de São Paulo, Adhemar de Barros, conhecido pelo bordão "rouba, mas faz". Da ação, resultou a obtenção de 2,5 milhões de dólares (GORENDER, 1987, p. 283).

Com o dinheiro em caixa foi realizado um novo congresso. Em apenas dois meses de existência da VAR-Palmares, os dissensos apareciam com força. A maioria dos presentes decidiu reduzir a inclinação militarista. Sete pessoas, entre elas Lamarca, se recusaram a aceitar o posicionamento e formaram a segunda versão da VPR, que agora contava com metade dos fundos obtidos e a maior parte das armas. Esse pequeno grupo prometia intensificar imediatamente a luta armada e a guerrilha rural (GORENDER, 1987, p. 136-137). Em pouco tempo, se iniciaria um foco guerrilheiro no Vale do Ribeira, em São Paulo, conforme apontam José e Miranda:

Ir para o campo, fazer a guerrilha: esse era o objetivo central da nova VPR e Lamarca saiu do congresso do "racha" com essa disposição. Agora era o comandante chefe da Organização e, junto com Fujimori e José Lavechia, percorreu os povoados do Vale do Ribeira, à procura de terras. Os 80 alqueires de um terreno acidentado, na altura do $\mathrm{km} 510$ da Rodovia Régis Bittencourt, no distrito de Capelinha, foram adquiridos por Monteiro, nome frio de Joaquim dos Santos, das mãos do ex-prefeito de Jacupiranga, Manoel de Lima. (JOSÉ; MIRANDA, 1980, p. 68)

Na mata que ocupava o terreno foram montadas duas bases; a primeira composta por dez militantes, chamada de "Carlos Roberto Zanirato" e, a segunda, denominada “Eremias Delizoikov”, ambas batizadas em homenagem a militantes da VPR assassinados pela repressão. O conjunto compunha o chamado núcleo “Carlos Marighella”, que também havia sido morto em novembro de 1969, e era comandado por Lamarca. A disciplina era severa e o treinamento rígido era intercalado por grupos de estudo de obras marxistas (JOSÉ; MIRANDA, 1980, p. 68-69). 
Em janeiro de 1970, todos os militantes apontados para o treinamento já haviam chegado ao local. O objetivo almejado pelos dezessete militantes da VPR, de montar um foco de guerrilha rural, porém, em pouco tempo seria frustrado. Em abril, foram presos alguns membros da VPR e delatada a área de treinamento. Segundo José e Miranda (1980, p. 70), os responsáveis teriam sido Massafumi Yoshinaga e Celso Lungaretti, enquanto Marcelo Rubens Paiva afirma que o único responsável fora Lungaretti (PAIVAa, 1994), apesar deste, em resposta, colocar que pode "ter sido responsável involuntário pelo episódio, mas não o delator que Marcelo Paiva pinta" (PAIVAb, 1994). Certo é que Lamarca descobriu a delação da localização da área de treinamento, relatando que:

No dia 19 de abril tivemos conhecimento de que a área de treinamento havia sido delatada. Decidimos que um grupo de oito companheiros a abandonasse o mais breve possível. Um segundo grupo de quatro tentaria sair na primeira oportunidade. Os outros cinco ficavam com a missão de defender o patrimônio. O primeiro grupo pôde sair, mas o segundo teve de permanecer. Ficariam na área nove companheiros. (JOSÉ; MIRANDA, 1980, p. 70)

Restaram no campo, além de Lamarca, Darcy Rodrigues, José Araújo Nóbrega, Gilberto Faria Lima, Ioshitane Fujimori, Edmauro Gopfert, Diógenes Sobrosa, Ariston Lucena e José Lavechia (JOSÉ; MIRANDA, 1980, p. 70-71). Enquanto isso, o II Exército, recebendo a informação, preparou um grande combate, colocando em campo, no dia 21 de abril, 1500 homens divididos em dez unidades diferentes. Na sua maioria, tratava-se de recrutas recém-entrados no serviço militar, mal armados e sem prática de tiro (GASPARI, 2014, p. 530).

Apesar do grande número de tropas e da utilização de helicópteros, os primeiros resultados demoraram a aparecer. Foi apenas em 27 de abril, após dias de perseguição, que os militares conseguiram capturar José Lavechia e Darcy Rodrigues, que estavam em um posto de observação. Lamarca aguardou o retorno dos companheiros e, percebendo que eles não voltariam, colocou o restante do grupo em marcha para sair do Vale do Ribeira (JOSÉ; MIRANDA, 1980, p. 74-75). Mesmo tentando fechar o cerco aos guerrilheiros, os militares ainda não haviam conseguido seu objetivo. No dia 8 de maio foi decidido que a operação seria suspensa, devendo permanecer apenas um pelotão na cidade de Registro, o qual seria comandado por um dos oficiais, o $2^{\circ}$ tenente Alberto Mendes Junior (TELHADA, 2011, p. 495-496). 
Na mesma data, após dias de marcha, os sete guerrilheiros restantes, fazendo-se passar por caçadores perdidos, entraram em um vilarejo e alugaram uma caminhonete Ford F-350 de um fazendeiro. Este, porém, enviou um de seus empregados à cidade de Eldorado para que alertasse a polícia. A descrição dos homens realizada aos policiais batia com a dos fugitivos procurados pelo exército e, tendo isso em vista, os policiais militares organizaram uma barreira na cidade (TELHADA, 2011, p 496-497). Por volta das dezenove horas, a caminhonete da VPR foi parada na barreira policial. Quando os policiais pediram que todos os ocupantes do veículo descessem para se identificar, os guerrilheiros desceram atirando. Dois policiais foram feridos na troca de disparos e Edmauro sofreu um tiro de raspão na cabeça. Continuando a disparar, o grupo de Lamarca conseguiu dispersar os policiais e seguiram adiante com a caminhonete (GASPARI, 2014, p. 531).

Passados trinta minutos da troca de tiros, o posto do Exército de Jacupiranga foi informado do ocorrido e enviou para Eldorado o pelotão do $6^{\circ}$ Regimento de Infantaria em direção aos chamados "terroristas". Pouco depois, a Polícia Militar recebeu a informação e foi dada a ordem para que o $1^{\circ}$ Batalhão Tobias Aguiar, comandado pelo tenente Mendes Junior, se deslocasse até o km 270 da BR-116. Os militares embarcaram em um caminhão de tropa e à frente iria uma perua Chevrolet C-14 com cinco policiais militares (TELHADA, 2011, p. 499-500). Após alguns quilômetros, o tenente Mendes Junior ordenou que quatro policiais descessem próximo a um cruzamento, para que montassem um ponto de fiscalização enquanto o restante seguiria adiante. Por volta das vinte e uma horas, pouco depois de passarem por Sete Barras, depararam-se com Lamarca e seus companheiros, conforme registrou o ex-capitão:

A quatro quilômetros de Sete Barras deu-se o encontro. Éramos sete num caminhão; o inimigo vinha com uma camioneta $\mathrm{C}-14$ na vanguarda $\mathrm{e}$ um caminhão [...] aproximadamente às 21 horas. O combate foi breve, mas feroz. Intenso tiroteio de três minutos. Dezesseis inimigos renderam-se. Um fugiu. $O$ efetivo do inimigo era composto por um tenente, dois sargentos, dois cabos e doze soldados. O inimigo rendeu-se por estar em inferioridade tática, apesar da superioridade numérica, e também porque não resistiu à guerra psicológica que desencadeamos para intimidá-lo à rendição. Socorremos imediatamente três feridos, um quarto podia manter-se em pé [...] os prisioneiros mostraram-se espantados com o nosso humanismo. (JOSÉ; MIRANDA, 1980, p. 77) 
Os guerrilheiros propuseram seus termos de rendição. Não fuzilariam os prisioneiros, atenderiam os feridos e, em troca, reabasteceriam suas munições sem tomar as armas e o tenente Mendes Junior os ajudaria a passar pelo bloqueio em Sete Barras (JOSÉ; MIRANDA, 1980, p. 78). Os soldados feridos seriam transportados a Sete Barras enquanto os demais permaneceriam como prisioneiros. Os feridos foram colocados na C14 acompanhados por Lamarca, Nóbrega e o tenente Mendes Junior. Os membros da VPR acompanharam a viatura até um local próximo à barreira localizada em Sete Barras, escondendo-se em um matagal enquanto o tenente conduzia os feridos até os policiais militares. Enquanto isso, os demais guerrilheiros abordaram uma caminhonete F-350 conduzida por civis, a expropriaram, carregaram o veículo com armamento e equipamentos, abandonaram os prisioneiros e seguiram viagem. Encontraram, então, Lamarca e Nóbrega na beira da estrada e, pouco depois, viram o tenente Mendes Junior que seguiu junto deles (TELHADA, 2011, p. 507), afirmando que não havia mais barreira em Sete Barras.

A chegada dos feridos gerou confusão. O tenente coronel do exército Haltemburgo reuniu a tropa e deslocou-a para as estradas de Sete Barras, Eldorado e São Miguel Arcanjo. Outra tropa, sob o comando do tenente coronel Mero Ferreira, sem saber disso, já estava próxima a Eldorado, onde chegou logo após o conflito. As duas tropas se encontraram e entraram em confronto devido às falhas de comunicação, à escuridão e ao mau tempo (TELHADA, 2011, p. 508).

Enquanto os militares combatiam a si mesmos, Lamarca e os demais guerrilheiros seguiram com o tenente Mendes Junior a bordo do caminhão expropriado até que este atolou, forçando-os a seguirem a pé, formando uma coluna organizada para enfrentar uma emboscada. Enquanto transitavam pela estrada, ouviram vozes e perceberam que se tratava dos militares. Os membros da VPR abandonaram a estrada e passaram pela emboscada pelo lado esquerdo, através de um lodaçal. Neste caminho, dois guerrilheiros se perderam dos demais (JOSÉ; MIRANDA, 1980, p. 78): Nóbrega foi capturado pelos militares no dia 10 e, Edmauro, no dia seguinte.

Os militares reagruparam o maior efetivo possível na caça aos guerrilheiros e no resgate do tenente Mendes Junior, montando barreiras e efetuando missões de busca. 
Diógenes discutiram o destino do militar. Mendes Junior traíra o acordo realizado e não poderia ser conduzido através do cerco realizado. Ainda, era impossível soltá-lo, já que iria informar a posição do grupo. Decidiram, então, executá-lo (JOSÉ; MIRANDA, 1980, p. 82).

A sentença deveria ser cumprida por fuzilamento, porém, como o grupo estava cercado por tropas, um tiro poderia revelar sua localização. O tenente Mendes foi morto a coronhadas de fuzil e enterrado. Meses depois do ocorrido, em setembro de 1970, Lamarca revelaria o ocorrido através de um manifesto ao povo brasileiro, apesar de relatar que o tenente teria sido fuzilado e o corpo jogado no Rio Ribeira (JOSÉ; MIRANDA, 1980, p. 82-83).

\section{Ariston Lucena: o início do processo}

Os fugitivos, apesar da amplitude das forças militares em sua busca, conseguiam escapar dos captores. Todas as vezes que se forçaram a procurar alimentos junto à população, foram delatados. Durante semanas foram aptos a fugir das emboscadas armadas e do forte aparato formado pelos militares, apesar da fome e do desgaste físico. No dia 30 de maio, foi decidido que Gilberto Faria Lima, o mais jovem e sem ficha na polícia, deveria sair e retornar a São Paulo em busca de ajuda. O militante da VPR conseguiu entrar em um ônibus da linha Sete Barras - São Miguel e fugiu. Os demais aguardaram o resgate que não teve tempo de chegar (GASPARI, 2014, p. 537).

No dia seguinte, desesperados pela sua situação precária, os quatro guerrilheiros restantes resolveram arriscar. Deslocaram-se até a estrada e atacaram um caminhão do exército, rendendo os cinco ocupantes, obrigando-os a se despir para que pudessem usar seu fardamento. Seguindo com o caminhão, conseguiram furar uma barreira afirmando se tratar de uma ordem de um coronel. À noite, Lamarca, Ariston, Diógenes e Fujimori abandonaram o caminhão na Marginal do Tietê, tiraram os uniformes, vestiram os 
Ariston Lucena caminhou oito quilômetros até chegar a São Paulo, onde pôde realizar um desejo que o perseguia durante os dias de fome no Vale do Ribeira: comer um sanduíche na lanchonete Rex na avenida São João. Depois, andou mais um pouco e parou na praça da Sé, onde ouviu o início da Copa do Mundo de futebol com a partida entre as seleções do México e da União Soviética. Ariston se deteve por um tempo para torcer pelos russos (GASPARI, 2014, p. 540-541).

A relação de Ariston com a resistência à ditadura não havia começado com seu ingresso na VPR e a ação no Vale do Ribeira. Na realidade, pode-se dizer que era uma condição herdada. Ariston era filho de Antonio Raimundo Lucena, conhecido como “Doutor” e Damaris Feitosa Quintanilha, ambos membros da VPR. Quando da decisão de militarizar a organização, foi montada uma oficina para produzir bombas e armamentos com algum sucesso. Esta oficina, denominada de "fábrica", era localizada na casa de Raimundo e Damaris em Atibaia (CHAGAS, 2000, p. 34).

Em 20 de fevereiro de 1970, a polícia localizou a "fábrica" e invadiu o local com ferocidade. Raimundo foi morto a tiros e Damaris foi presa e indiciada com fundamento na Lei de Segurança Nacional juntamente com Ariston, que estava foragido, devido à apreensão de "grande quantidade de material subversivo entre os quais armas furtadas do IV RI, ou sejam, fuzis FAL privativos da Forças armadas, bem como outros tipos de armas, grande quantidade de munição e de equipamento médico e medicamentos" (DEOPSa).

Em 19 de agosto, pouco mais de dois meses após a sua chegada em São Paulo, Ariston foi preso em uma batida policial na Vila Mariana. Detido e torturado, Ariston seria alvo de um dos processos mais emblemáticos do período ditatorial brasileiro.

Antes de iniciar a tratar acerca do processo contra Ariston, cabe uma breve exposição a respeito das instâncias da Justiça Militar. A primeira fase do processo iniciavase a partir da denúncia do procurador, que poderia ser aceita ou recusada pelo juiz auditor de uma das Auditorias Militares. Aceita a denúncia, ocorria a citação do acusado e 
Militar podiam recorrer da decisão de primeira instância, sendo que os recursos eram julgados pelo Superior Tribunal Militar. O STF, por sua vez, atuava como a instância máxima, podendo reverter as decisões dos tribunais militares (TELES, 2013, p. 5). Com esta sucinta explanação, é possível regressar ao caso em análise.

Em 05 de abril de 1971, o Procurador Militar Duraval A. Moura de Araujo denunciou Carlos Lamarca, Gilberto Faria Lima e Ariston de Oliveira Lucena com fundamento, em relação a Lamarca, no art. 28, parágrafo único, e art. 49, incisos I e III, do Decreto Lei $898 / 69$ e, no que diz respeito a Gilberto e Ariston, nos artigos 28 do mesmo Decreto Lei, o qual definia os chamados crimes contra a segurança nacional e 53, do Código Penal Militar (CPM). Enquanto o artigo 53 do CPM dizia respeito à coautoria, o artigo 28 da do Decreto Lei 898/69 era fruto da alteração constitucional realizada pelo Ato Institucional $n^{\circ} 14$, o qual permitia o estabelecimento da pena de morte "nos casos de guerra externa psicológica adversa, ou revolucionária ou subversiva nos termos que a lei determinar", vindo a dispor o seguinte:

Art. 28. Devastar, saquear, assaltar, roubar, sequestrar, incendiar, depredar ou praticar atentado pessoal, ato de massacre, sabotagem ou terrorismo:

Pena: reclusão, de 12 a 30 anos.

Parágrafo único. Se, da prática do ato, resultar morte:

Pena: prisão perpétua, em grau mínimo, e morte, em grau máximo.

A previsão acerca da pena de morte era uma vitória da chamada "linha dura" dos militares após ações das organizações de resistência à ditadura, conforme expõe Angela Moreira Domingues da Silva:

Percebe-se, portanto, que o "estopim" para a decretação do Al-14 foi, justamente, o sequestro do embaixador dos Estados Unidos no Brasil. Apesar de saber-se ainda muito pouco sobre as discussões travadas no seio das Forças Armadas a respeito da inserção da pena de morte no quadro penal brasileiro, bem como quais foram seus referenciais, acredita-se que esta fazia parte de uma lógica de institucionalização, recrudescimento e legitimação do chamado grupo "linha dura", iniciada com a decretação do Al-5, em dezembro de 1968 (SILVA, 2016). 
Importante ressaltar neste momento que a existência da chamada "linha dura" militar e seu próprio impacto na Justiça Militar é alvo de controvérsias entre os pesquisadores. Neste sentido temos, por exemplo, a afirmação de João Roberto Martins Filho:

Depois do expurgo das forças castrenses nacionalistas e populares, a paisagem das correntes políticas atuantes nas Forças Armadas brasileiras caracteriza-se por uma pluralidade de posições e por uma complexidade de fatores de desunião e cizânia que impede uma análise em termos duais. (MARTINS FILHO, 1996, p. 114)

A denúncia era baseada nas ações da VPR no Vale do Ribeira e, especialmente, no assassinato do tenente Mendes Junior. O único denunciado preso era Ariston Lucena. Lamarca estava foragido, assim como Gilberto Faria Lima, cujo destino, até a atualidade, é controvertido, uma vez que desapareceu após conseguir fugir para o Chile.

No dia de sua prisão, Ariston Lucena foi encaminhado pelo delegado do Deops para interrogatório. No termo constam informações a respeito de Ariston, desde seus pais e suas atividades, sua chegada à área de treinamento em Jacupiranga até o nome de seus companheiros que participaram da guerrilha no Vale do Ribeira. Quanto à morte do Tenente Mendes Junior, Ariston afirmou que ele, após um encontro entre Lamarca, “Carlos" e Fujimori, questionou a respeito do militar pois notara a ausência deste, quando foi informado que ele teria sido executado por traição. Disse ainda que não sabia onde se encontrava o corpo, uma vez que só teria ouvido de Lamarca que este havia sido jogado no rio Ribeira, seguindo a declaração divulgada pelo ex-capitão. Consta no termo também o seu relato sobre os acontecimentos posteriores, sua fuga da área do Vale do Ribeira e, por fim, sua prisão.

O documento seguinte, juntado aos autos, é o exame necroscópico do cadáver do tenente Mendes Junior. A análise realizada em 09 de setembro só foi possível em virtude da captura de Ariston Lucena. Após ser interrogado continuamente e sofrendo tortura, Lucena foi levado pelos militares de volta ao Vale do Ribeira, onde tentou em um primeiro momento enganar seus captores, mas acabou por revelar o local onde o tenente estava enterrado (TELHADA, 2011, p. 522). O exame necroscópico revelou, apesar do estado 
antes da descoberta do corpo, em 01 de setembro. Trata-se de um longo registro, contando com quase quatorze páginas do relatado pelo guerrilheiro. Cumpre ressaltar que Lucena, interrogado no DEOPS paulista, estava preso no famigerado presídio Tiradentes, local conhecido pelas torturas impostas aos seus presos. Assim, todas as informações constantes não podem ser encaradas como delações, mas sim como resultado do sofrimento do prisioneiro.

O início do relato diz respeito às atividades do seu pai, o "Doutor", a partir do que foi transcrito como a "Revolução de 1964", e sua relação com outras pessoas, a exemplo dos conhecidos Pedro Lobo e Onofre Pinto. Posteriormente, passou-se ao início de sua participação no MNR quando ainda era menor de idade e seu ingresso na VPR. É relatado seu encontro com Lamarca e seu conhecimento acerca dos planos em relação ao $4^{\circ} \mathrm{RI}$. Os passos dados até se chegar ao campo de treinamento no Vale do Ribeira são minuciosos e constam os nomes de diversos guerrilheiros que se encontraram no local, a divisão do campo e as atividades realizadas. Os conflitos com os policiais e militares também são contados de forma acurada e detalhada, merecendo destaque o disposto a respeito da morte do tenente Mendes Junior ocorrida após a reunião de Lamarca, Fujimori e Araújo:

Momento após retornaram e imediatamente FUJIMORE desfechou um golpe na cabeça do Tenente MENDES, que caiu, enquanto que continuava sendo agredido já agora também por "Araujo". O interrogando assustou com a atitude de FUJIMORI e ao ver que matavam o tenente ficou [ilegível] a ponto de começar a chorar. LAMARCA vendo a atitude e o estado do interrogando, disse-lhe que "êles mataram o seu pai e agora você fica chorando pela morte de um deles", dizendo ainda que assumia a responsabilidade pela morte do Tenente, mandando em seguida que fosse enterrado. (BRASIL, 1971, p. 351)

Posteriormente, Lucena revelou a respeito dos demais atos tomados pelo grupo e sua fuga. Relatou também que, após passar por São Paulo, rumou a Santos, onde continuou se encontrando com Fujimori e participou de furtos de placas de automóveis, um roubo e levantamentos de agências bancárias passíveis de assalto e observação da 
residência do cônsul da Holanda para fins de sequestro, citando nomes de pessoas com quem agiu. $\mathrm{O}$ auto de interrogatório foi assinado por um advogado, nomeado curador de Ariston por este ser menor de 21 anos, por duas testemunhas, pelo delegado e um escrivão de polícia.

Ariston Lucena foi citado da denúncia oferecida em 19 de abril de 1971, sendo indicado que teria prazo de dez dias para nomear advogado, arrolar testemunhas e oferecer defesa escrita. Os outros três réus, Lamarca, Gilberto e Fujimori, não foram citados. Os primeiros por estarem foragidos e o terceiro por ter sido morto em dezembro de 1970. Procedeu-se a citação por edital dos foragidos.

Vergílio Egídio Lopes Enei foi indicado por Ariston como seu defensor. A possibilidade de executar uma defesa de qualidade era quase uma impossibilidade para os advogados que agiam em prol dos réus na justiça militar. Como aponta Wilma Antunes Maciel (2006, p. 154)., “a defesa existia como parte do 'teatro', mas não podia roubar a cena. Seu papel fazia parte da aparente 'legalidade', do caráter ambíguo, ou seja, da própria essência da administração da Justiça e da lógica do Estado, de sua razão de ser" Em primeiro lugar, vinha o cumprimento da função de dar ao processo uma carapaça de legalidade, a efetividade da defesa restava em último plano. Isso fica claro quando é verificada a primeira peça da defesa direcionada ao juiz auditor da $2^{\mathrm{a}}$ auditoria da $2^{\mathrm{a}}$ Câmara da Justiça Militar:

Impedido de se avistar com seu constituinte, uma vez que este se encontra detido na OBAN, incomunicável mesmo para seu advogado, não tem meios o peticionário de oferecer defesa escrita, nem de arrolar testemunhas como prevê o art. 85 do DL 898.

Solicita, pois, as dignas providências de V. Exa. Para que possa ser exercido o direito de defesa que as leis do País conferem a todos os brasileiros, consistentes em autorizar a comunicação do defensor com o acusado, uma vez que a acusação é das mais graves. (BRASIL,1971, p. 373)

Apesar de todas as dificuldades, restrições e cerceamentos que sofriam os advogados de defesa, é necessário afirmar que, ainda que de modo restrito, muitos causídicos conseguiram se contrapor às ilegalidades operadas contra seus clientes, como aponta Mattos (2002, p. 83):: “Do ponto de vista dos réus, fez diferença ter advogados atuando em sua defesa (ainda que limitados em suas possibilidades de ação). Os 
Ariston, tornando possível que realizasse uma defesa de apenas uma página, datada de 17 de maio de 1971, em que negou a participação no crime e alegou que não era possível naquela situação que tivesse uma conduta diversa. Realizada a defesa, foram arroladas e ouvidas testemunhas de acusação. Ariston foi novamente interrogado, mudando o que havia exposto anteriormente. Desta vez, afirmou que Lamarca havia decidido que o tenente deveria ser "justiçado" e "todos nós silenciamos de que estávamos de [...] pleno acordo e irritados com o tenente que havia traído a nossa confiança”. Disse, então, que apenas Fujimori havia participado do assassinato, e que anteriormente tinha afirmado “sob sevícias" que Diógenes Sobrosa também dera coronhadas em Mendes Junior.

Dois fatos merecem destaque a respeito do interrogatório de Lucena realizado no decurso do processo judicial: primeiramente a sua menção a Sobrosa. Até então, o nome de Diógenes Sobrosa de Souza não havia tido destaque no processo, até porque no primeiro interrogatório de Ariston aparecia o codinome "Araújo", que parecia se referir a José Araújo da Nóbrega. Agora, Ariston deixava claro que o sujeito citado era Diógenes. O segundo fato é que o interrogando disse que apenas havia afirmado a participação de uma segunda pessoa no assassinato do tenente por estar "sob sevícias", ou seja, por ter sido alvo de tortura no momento do interrogatório.

Com a citação do nome de Diógenes e dos demais que participaram das ações no Vale do Ribeira, o processo tomou um novo rumo. Ao fim do interrogatório, o procurador pediu vistas ao processo para que revisasse sua denúncia. Em 07 de junho, o procurador Durval Moura de Araújo realizou um requerimento à Auditoria solicitando a ratificação da denúncia contra Lamarca, da denúncia contra Ariston Lucena, Gilberto Faria Lima e Diógenes Sobrosa de Souza nas sanções do artigo 28, parágrafo único, do Decreto Lei 898/69 e da denúncia de Edmauro Gopfert e José Araújo da Nóbrega baseada no caput do mesmo artigo. A partir da aceitação das denúncias, quatro membros da VPR poderiam ser condenados à morte: Lamarca, Ariston, Gilberto e Diógenes. Enquanto Gilberto Faria 


\section{Diógenes Sobrosa de Souza: condenados à morte}

Diógenes Sobrosa de Souza havia sido soldado da Brigada Militar do Rio Grande do Sul e operário da Siderúrgica Riograndense, em Esteio/RS, antes de ingressar na VPR. Tendo escapado do cerco do Vale do Ribeira, juntamente com Lamarca e os demais guerrilheiros, foi preso em 12 de dezembro de 1970 no Rio Grande do Sul (DEOPSb).

A defesa prévia de Sobrosa foi assinada pela advogada Lourdes do Valle em 25 de junho de 1971. O início da defesa foi voltado para o fato de que o acusado não poderia ser responsabilizado, uma vez que foi "mal orientado pelo seu próprio tio, levando-o para o caminho do terrorismo", utilizando de uma tática exposta por Maciel ao colocar que uma das estratégias mais comuns em processos na Justiça Militar era "alegar juventude ou imaturidade, mostrando o réu como alguém influenciável, comandado e que podia, em certos casos, arrepender-se de sua opção política pela luta armada" (2006, p. 166), coadunando também com a sequência da defesa, em que a advogada expõe que Diógenes não era bem visto dentro do grupo "por estar arrependido de ter tomado aquele caminho". Quanto ao assassinato do tenente Mendes Junior, Sobrosa não poderia ser considerado culpado pois não contribuiu para a morte.

Se, por um lado, essas estratégias eram voltadas a auxiliar os réus, por outro, podemos citar novamente Wilma Antunes Maciel que expõe:

Esse caminho adotado mostrava a complexidade da administração da Justiça durante o regime militar. No esforço de amenizar as penas elevadas das condenações, sob a alegação de ingenuidade, juventude, arrependimento, de certa forma vitimizando os militantes, ou individualizando suas ações, tais estratégias levavam a uma descaracterização da opção política de um projeto coletivo e mesmo, em algumas argumentações, à desqualificação da pessoa do militante. (MACIEL, 2006, p. 167)

No dia 12 de julho, Diógenes Sobrosa de Souza foi interrogado na $2^{\mathrm{a}}$ Auditoria. Já inicialmente declarou que a denúncia era verdadeira. Posteriormente, relatou sobre sua 
Sobre o assassinato do tenente, Sobrosa afirmou que não havia sido comunicada a decisão de "justiçar" o tenente, tendo Fujimori regressado de uma conversa com Lamarca e subitamente golpeado Mendes na cabeça. Fujimori ainda teria ordenado a ele que também golpeasse, fato que Diógenes confessou ter realizado. Por fim, afirmou que participou posteriormente de três ações da VPR e do MCR (Movimento Comunista Revolucionário) em Porto Alegre, sendo dois assaltos e um roubo de veículo.

Após o interrogatório, foi realizada a confrontação entre Ariston e Diógenes para esclarecer os fatos controversos relatados por ambos. Ariston disse não saber por que Diógenes afirmava ter golpeado o tenente Mendes, uma vez que o único responsável havia sido Fujimori; que o corpo foi enterrado depois de uma hora e que Lamarca havia anunciado que Mendes seria morto. Diógenes, por sua vez, afirmou que o enterro teria ocorrido quatro horas depois, que se Lamarca anunciou algo ele não teria ouvido e que havia assumido ter golpeado o tenente por conta própria já que "ninguém ameaçou o interrogando no sentido de que, se este não se acusasse perante o Conselho de Justiça, voltaria a ser seviciado". Destaque-se a palavra voltaria. Ficava claro que Sobrosa também havia sido alvo de tortura para admitir sua participação no ato.

Posteriormente, foram ouvidas outras testemunhas de acusação; militares que estavam presentes nas ações criminosas realizadas pelos réus. Enquanto os acusados não possuíam provas ou testemunhas que viessem em seu favor, a acusação não tinha problemas em encontrar provas contrárias aos réus. Passada a produção de provas, as partes realizaram suas razões finais.

As razões finais do procurador foram longas, retomando elementos de importância para a acusação, como o fato de Ariston contar com 19 anos de idade quando do assassinato do tenente Mendes Junior e a impossibilidade de seguir a denúncia contra Edmauro Gopfert e José Araujo da Nóbrega, uma vez que estes haviam sido banidos do país quando do sequestro do embaixador da Alemanha. O procurador ainda descreveu novamente os fatos imputados aos acusados Lamarca, Lucena, Sobrosa e Lima, 

circunstâncias em que o foi o assassinato do Ten. Mendes, adeptos da aplicação da pena de morte", mesmo a Ariston que era, à época dos fatos, menor de idade, uma vez que essa circunstância não deveria ser observada diante da periculosidade do acusado.

As razões finais de Gilberto Faria Lima, Diógenes Sobrosa de Souza e Carlos Lamarca ficaram a cargo de Juarez de Alencar. Após discorrer sobre a acusação, o advogado alegou que a prova de culpa constante nos autos havia sido realizada livremente, enquanto os réus se encontravam presos e incomunicáveis, tratando-se de pessoas simples e jovens.

Novamente se apelava à pouca instrução e capacidade dos réus, mais especificamente neste caso, à de Diógenes Sobrosa. O advogado seguiu, então, colocando que, diante dessa pouca elevação intelectual, os réus não poderiam ser considerados dirigentes, estando submissos às vontades de Lamarca e Fujimori. A pena de morte, diante disto, deveria ser aplicada apenas aos comandantes, uma vez que “mesmo em estado de guerra revolucionária, só quem dá ordem, só quem comanda é que é o responsável pelo ato criminoso praticado e não quem cumpre a ordem". Assim, requereu que a pena de morte fosse comutada em prisão perpétua e esta em reclusão de 30 anos, para que se desse um sentido humano ao aspecto drástico da pena máxima.

Deve-se grifar o apelo que o defensor fez à questão da hierarquia, tão cara aos militares. Tratava-se de mais uma estratégia de defesa disseminada nos tribunais militares, como expõe Wilma Antunes Maciel: “a percepção por parte dos advogados desse conceito fundamental (hierarquia) para as Forças Armadas tornou-se um argumento recorrente, sendo utilizado de diferentes maneiras, levando mesmo à absolvição dos réus" (2006, p. 157). Por se tratar de um preceito fundamental das Forças Armadas, mesmo os julgadores dos tribunais militares possuíam barreiras em admitir a quebra de uma cadeia de comando e a responsabilização daqueles que cumpriam ordens de superiores. 
O advogado Virgilio E. Lopes Enei apresentou as razões finais em nome de Ariston de Oliveira Lucena. Enei, que já havia realizado uma defesa prévia sucinta, não destoou de seu estilo, efetuando as razões finais em apenas duas páginas, restringindo-se a expor pensamento doutrinário contrário à pena de morte de Nelson Hugria e Boaventura de Souza Santos, e colocando que se pronunciaria sobre a culpa do acusado em plenário.

O documento seguinte, anexado ao processo, foi a certidão de óbito de Carlos Lamarca, onde constava que ele havia morrido em 17 de setembro em Brotas de Macaúbas, na Bahia, tendo por motivo “Anemia aguda. Hemorragia interna e externa. Lesões em ambos os pulmões e coração". O pedido do procurador quanto a Lamarca de nada mais valia, a pena de morte já havia sido aplicada ao “Capitão da Revolução”.

A sessão de julgamento ocorreu em 22 de novembro. O procurador Duraval A. Moura de Araujo e os advogados Juarez A. A. de Alencar, por Diógenes, e Rosa Maria Cardoso da Cunha, agora defensora de Ariston, reiteraram seus argumentos realizados nas alegações escritas. Reuniu-se, então, o Conselho Especial de Justiça em sessão secreta, após a qual proferiu sua sentença, em 29 de novembro:

\begin{abstract}
1- Julgar procedente a denúncia para condenar DIOGENES SOBROSA DE SOUZA, ARISTON DE OLIVEIRA LUCENA E GILBERTO FARIA LIMA à morte; 2- Declarar extinta a punibilidade de CARLOS LAMARCA E IOSHITANE FUGIMORE, com base no artigo 59, letra "a" da Lei de Segurança Nacional; 3 - Declarar sobrestado o processo quanto a José Araujo da Nóbrega e Edmauro Gopfert, com base no disposto no artigo $1^{\circ}$ $\S$ único do A.I. 13; 4 - Recorrer, de ofício, ao Egrégio Superior Tribunal Militar da Sentença que condenou os três referidos réus à pena máxima. (BRASIL, 1971)
\end{abstract}

Salta aos olhos a forma como poucas páginas de escritos podem impactar na vida das pessoas. Agora Ariston e Diógenes eram condenados à morte, a qual deveria se dar por fuzilamento, segundo o artigo 56 do Código Penal Militar. A decisão quanto à pena se deu por maioria. Foram favoráveis, o tenente coronel Lionel Comegna, o major Carlos Aberto Barreiro da Silveira e o civil Nelson da Silva Machado Magalhães; e foi voto vencido, o coronel Pedro Lúcio Tosin que se posicionou no sentido de condenar os réus à prisão perpétua. A sentença ainda teria de ser analisada pelo Superior Tribunal Militar (STM) em virtude da aplicação da pena de morte. 
Enquanto, no dia 29 de novembro, Diógenes Sobrosa constituía como procuradores Virgílio E. Lopes Enei, que já atuava em seu processo, Rosa Maria Cardoso da Cunha, que defendera Ariston, e Nilo Batista, para que o defendessem no restante do processo, quatro dias antes Lucena havia escrito uma carta de próprio punho e que foi juntada aos autos:

Esta tem a finalidade de comunicar que não autorizo nem um advogado a apelar de qual quer sentença que me seja imposta. Isto quer dizer que estão caçados os poderes de meus advogados após o julgamento. Não apelo mesmo que seja condenado à morte. São Paulo 25/11/1971 (BRASIL, 1971)

Pode-se inferir que a sentença se tratou de uma vitória especial para o Procurador Durval de Araújo e o juiz auditor Nelson da Silva Machado Magalhães, os quais possuíam um relacionamento pessoal, segundo Percival de Souza, que também afirma que Durval apenas formalizava aquilo que os captores desejavam, contando sempre com a cumplicidade de Magalhães, sendo que os dois faziam parte da "repressão togada", frequentando constantemente o DOPS e a OBRAN em almoços e jantares (apud MACIEL, 2006, p. 148).

No dia 10 de dezembro, em reunião do Conselho Especial de Justiça, foi lida a sentença. Juarez de Alencar, advogado de ofício de Gilberto Faria Lima, informou que apelaria ao STM, sendo seguido por Rosa Maria Cardoso da Cunha, que colocou que também apelaria em nome de Diógenes e pedia que fosse reunida com Ariston para conversar com ele sobre a possibilidade de apelação diante do bilhete que o réu escrevera. No dia seguinte, Ariston escreveu um novo bilhete que abria a possibilidade de recurso e revelava a situação de maus tratos imposta a ele:

ARISTON OLIVEIRA LUCENA, condenado à morte por essa auditoria, atualmente detido no pavilhão cinco da Casa de Detenção, em total isolamento, vem por meio desta solicitar a autorização para tomar banho de sol pelo menos uma vez por semana, e autorização para receber visita de sua família. Pede também autorização para receber livros.

Pede ainda que seja devolvida a seus familiares a quantia de cento e vinte e cinco cruzeiros que foi apreendida pela Operação bandeirantes (sic) quando da sua passagem por lá a caminho da Casa de Detenção.

Sabendo que a apelação da sentença de morte é obrigatória vem renovar a procuração que tinha dado a seus advogados Virgilio e Rosa Maria, para que prossigam na sua defesa. (BRASIL, 1971) 
Em 16 de dezembro, foi recebido também o recurso de Ariston Lucena. Agora, a decisão a respeito dos condenados à morte caberia ao Superior Tribunal Militar, instância máxima deste ramo da esfera judicial.

\section{Os recursos dos condenados}

O recurso realizado pelo advogado Juarez de Alencar em relação a Gilberto Faria Lima iniciou tratando da própria pena de morte, a qual só poderia ser aplicada em caso de guerra externa ou interna, sendo que a segunda teria sido reconhecida implicitamente pela Auditoria na sua espécie guerra revolucionária. A partir de então, volta o advogado a defender o argumento de que Gilberto teria sido somente um subordinado a Lamarca e, invocando novamente o princípio da hierarquia, pediu que fosse o réu condenado com base no artigo 35 da Lei de Segurança Nacional, com pena entre 12 e 30 anos, e a condenação de 18 anos de reclusão.

A defesa de Diógenes Sobrosa de Souza, em sua apelação, também partiu para a desqualificação de seu cliente, inserindo-o também como um subordinado e colocando que ele "não foi líder, senão liderado; não foi um aliciador, senão aliciado; não foi incitador, senão incitado. Por sua infelicidade, veio a tomar contato com um grupo clandestino de excepcional radicalismo, e afinal veio a assistir ao repugnante assassinato". Foi argumentado, então, que a única prova da participação do réu no crime foi sua confissão, a qual foi desmentida pelo corréu Ariston Lucena e não teria sido corroborada por qualquer outra prova. Gize-se que em momento algum alegou-se que a confissão teria sido obtida através de tortura, argumento que revelaria a realidade do tratamento sofrido por membros da resistência durante o regime militar, mas provavelmente não surtiria efeito no tribunal.

Passou, então, a apelação, a versar sobre a condição de mero obediente a ordens, ou, segundo constante na peça, um "robot (sic), um desgraçado que já perdera a sua verticalidade pela obra insidiosa da experiência do ódio". A culpabilidade deveria recair, então, em seu superior hierárquico: Lamarca. Por fim, argumentou contrariamente à pena de morte, a qual seria oposta à "índole de nossa nação, que vive numa terra de trabalho 

que não fosse aplicada a pena de morte. Nos autos, constantes no banco de dados do projeto Brasil Nunca Mais, não consta a apelação de Ariston Lucena, impedindo que seja realizada uma análise dos argumentos utilizados por seus defensores.

A resposta do apelado, o Ministério Público Militar, foi apresentada pelo procurador Henrique Vailati Filho em função das férias de Durval Ayrton Moura de Araujo. Pode-se denotar na peça de apenas uma página e meia, uma mudança clara no tom da acusação que antes buscava veementemente a aplicação da pena de morte. Apesar de pedir a manutenção da sentença em virtude dos fatos apresentados no processo, um parágrafo chama atenção: "Uma cousa, todavia, merece um relêvo especial: face à gravidade da punição, há de se examinar a prova com máxima cautela pois a reparação de um êrro judiciário é impossível”. Mesmo pedindo a condenação, a própria procuradoria exigia cuidado ao tribunal.

Remetidos os autos ao STM, foi realizado um parecer da Procuradoria Geral pelo subprocurador geral Leonam Nobre. Neste parecer, o subprocurador elogia a atitude do procurador e dos juízes prolatores da sentença, dizendo que esta seria irretocável e acertada, comparando o crime atribuído aos réus ao de lesa pátria, fato que justificaria a aplicação da pena de morte. Opinou, então, pela manutenção da sentença.

O STM, segundo Lemos, ocupava uma posição de destaque no regime militar, operando com uma função dúplice: primeiramente, a de órgão central do aparato de coerção jurídica, tendo suas funções aumentadas diante do progressivo esvaziamento de competência da justiça civil, em especial do STF. Em segundo lugar, como instrumento de legitimação do regime. Nas palavras de Lemos (2004, p. 424-425).: "contribuía para disseminar a ideia de que o regime contava com uma corte empenhada em respeitar os fundamentos jurídicos da democracia e os direitos dos presos políticos" Tais aspectos podem ser vistos nos casos em tela, assim como na decisão do STM. 
O acórdão do Superior Tribunal Militar, datado de 30 de junho de 1972, teve por relator o Ministro Amarílio Lopes Salgado e, como revisor, o tenente brigadeiro Gabriel Grun Moss. Inicialmente foi realizado um resumo dos fatos narrados no processo e dos atos realizados em seu curso. Diante das provas quanto à participação dos réus no assassinato do tenente Mendes Junior, entendeu o Tribunal que não haveria dúvidas do enquadramento dos apelantes no artigo 28, parágrafo único da Lei de Segurança Nacional, na condição de coautores. Passando a tratar especificamente de Ariston e Diógenes, uma vez que Gilberto era foragido, é colocado sobre Lucena que: "embora menor de 21 anos já possuía um rosário de crimes", enquanto Diógenes, apesar da alegação da defesa, "foi que deu a última coronhada na cabeça do tenente Mendes". Comprovado, portanto o crime, caberia a aplicação da pena, a qual, nos dizeres do acórdão, teria "apenas dois limites: mínimo e máximo. Prisão perpétua e morte". Por maioria de votos, reformaram parcialmente a sentença e optaram pelo limite mínimo proposto pelo relator, condenando os três apelantes à prisão perpétua.

Votaram a favor da prisão perpétua os ministros Amarilio Lopes Salgado, relator do processo, tenente brigadeiro Armando Perdigão, almirante de esquadra Silvio Monteiro Moutinho, almirante de esquadra Mario Cavalcanti de Albuquerque, general de exército Adalberto Pereira dos Santos, Waldemar Tôrres da Costa, general de exército Syseno Sarmento, tenente brigadeiro Carlos Alberto H. de O. Sampaio e Jacy Guimarães Pinheiro.

Foram vencidos os ministros almirante de esquadra, Waldemar de Figueiredo Costa, Presidente do Tribunal, Alcides Vieira Carneiro, general de exército Jurandir de Bizarria Mamede, Nelson Barbosa Sampaio e general de exército Augusto Fragoso e tenente brigadeiro Gabriel Grun Moss, os quais votaram pela aplicação de pena de reclusão com prazo delimitado a pelo menos um dos réus, revelando uma posição divergente da do relator que não aceitava penalidade diversa da prisão perpétua ou condenação à morte.

É importante expormos as razões do voto do tenente brigadeiro Grun Moss que constam no processo. Este, após colocar um resumo dos fatos descritos no processo, votou pela aplicação de prisão perpétua apenas a Diógenes Sobrosa de Souza, enquanto 
Em 21 de outubro de 1972, a defesa de Ariston Lucena realizou recurso de embargos da decisão do STM, alegando que ele não poderia ser considerado responsável pela morte do tenente Mendes Junior e que seis ministros daquele Tribunal haviam votado no sentido de condená-lo a penas entre 15 e 30 anos de prisão. Ainda, argumentaram que ele teria participado somente do sequestro do tenente, e não de sua morte, devendo ser aplicada, no máximo, a pena de 30 anos, levando-se também em conta que se tratava de réu primário e menor de idade à época do crime, o que reduziria a pena. O procurador Milton Menezes da Costa Filho deu parecer contrário aos embargos diante da "irrecuperabilidade" de Ariston e sugeriu inclusive que tivesse sido feito um exame de sanidade mental no embargante. Após a resposta da defesa de Ariston ao parecer, foram julgados os embargos em og de agosto de 1973.

Depois de uma nova exposição dos fatos atribuídos a Ariston e de discorrer sobre o ocorrido no processo, o acórdão traz a conclusão sobre o requerimento realizado pela defesa, devendo-se ressaltar o constante em sua última parte:

O embargante é um jovem que teria praticado o crime que lhe foi atribuído aos 18 anos de idade. Filho de pai subversivo, eliminado pela Polícia e de mãe foragida, pelo mesmo motivo. Não teve, sequer, o curso primário. Um autêntico filho das ruas, com uma breve infância, repleta de revolta, insatisfação e ressentimento. Era a massa adequada aos cruéis desígnios de LAMARCA, que o mobilizou, amoldou, transviou-o, levandoo a presenciar as grandes tragédias da vida, que os desalmados amam, como os homens de boa formação amam a paz, a misericórdia e a justiça. (BRASIL, 1971)

Diante disso, tendo em vista a vulnerabilidade do embargante Ariston, por maioria de votos, foram acolhidos os embargos e Ariston Lucena foi condenado a 30 anos de reclusão, sendo afastada a prisão perpétua. O acórdão do STM seguiu a linha exposta por Lemos ao dizer que: 
[...] o STM tendeu a atuar de maneira relativamente moderada. Julgava de acordo com a legislação derivada da Doutrina de Segurança Nacional e com base em processos construídos a partir de práticas violentas (prisões arbitrárias, confissões obtidas à base de torturas etc.), mas, com frequência, reduzia penas propostas na primeira instância. (LEMOS, 2004, p. 425)

A procuradoria da Justiça Militar não ficou satisfeita com a vitória de Ariston e realizou recurso ordinário ao Supremo Tribunal Federal em 04 de novembro de 1973, com razões protocoladas em 10 de dezembro, alegando que Lucena "não fora mobilizado, amoldado, transviado pelo ex-Cap. LAMARCA", mas era, sim, um "jovem de 18 anos pronto para agir em qualquer operação bélica” e, responsável pelo crime, deveria ser mantida a pena de prisão perpétua. A defesa de Ariston também tentou realizar recurso para o STF, porém agiu tardiamente e o mesmo não foi aceito por ter sido feito fora do prazo.

Enquanto o destino de Ariston Lucena estava prestes a ser definido, o mesmo não se podia dizer a respeito de Diógenes. Regressando na linha cronológica, a defesa de Diógenes Sobrosa foi intimada do acórdão apenas em 01 de dezembro de 1972, tendo conhecimento do seu conteúdo apenas nesta data em virtude de um equívoco na remessa dos autos e, três dias depois, realizaram um recurso ordinário direcionado ao Supremo Tribunal Federal (STF) requerendo a alteração da decisão. Novamente foi alegado o fato de que a confissão de Diógenes não poderia ser utilizada já que era a única menção à participação direta do recorrente na morte do tenente Mendes Junior, não existindo, assim, provas suficientes para a sua condenação. Ainda, foi colocado que não se poderia exigir um comportamento diverso de Diógenes nas circunstâncias em que o crime foi cometido e que ele deveria ser condenado somente pelo sequestro e não pelo homicídio.

Os recursos do Ministério Público Militar e de Diógenes Sobrosa de Souza foram julgados em conjunto pelo Supremo Tribunal Federal após parecer do Procurador da República contrário ao provimento de ambos. O relatório do caso coube ao ministro Aliomar Baleeiro, que realizou um sucinto resumo do processo e foi o primeiro a proferir seu voto em 16 de agosto de 1974. Primeiramente, o ministro ressaltou que as condenações de Diógenes e Ariston foram resultado apenas das suas confissões, as quais 
eram conflitantes. Na sequência, Baleeiro procurou se desprender de sua condição de julgador com o intento de compreender a situação em que o crime foi cometido, evitando julgamentos precipitados:

A meu ver a situação não deve ser medida psicologicamente pela frieza mental de velhos juízes, tranquilamente sentados numa sala calma e silenciosa a $1.000 \mathrm{~km}$ e a 3 anos dos fatos, mas tal como ela se apresentou ao espírito conturbado dos protagonistas do drama, armas em punho, nas trevas, e no perigo da vida, segundo suas concepções pessoais de hierarquia de tropa irregular e das regras de lealdade entre combatentes de um e doutro lado. Creio que Lamarca, segundo a legenda da época, não era um disciplinador maleável nem se preocuparia de organizar um Conselho de Guerra para condenar e mandar executar um inimigo que faltara à palavra e o fizera perder dois homens na emboscada. Agiu de plano e por autoridade própria. (BRASIL, 1971)

Aceitava, assim, o ministro, o principal argumento das defesas dos réus: o responsável pelo assassinato do tenente Mendes Junior era Lamarca, enquanto Ariston e Diógenes eram meras partes de uma engrenagem maior, submetidos à hierarquia. Desta forma, negou de pronto o provimento do recurso do procurador militar quanto a Ariston, mantendo a pena de reclusão por 30 anos. Quanto à Diógenes, discordou o ministro do parecer do procurador geral, entendendo que, assim como ocorrera com Lucena, ele também deveria ter sua pena convertida de perpétua para fixa em 30 anos de reclusão. Finalizou seu voto afirmando que, caso o recurso feito pela defesa de Ariston houvesse sido realizado dentro do prazo, ele entenderia também pela redução da sua penalidade, talvez para 15 anos de reclusão. Após o voto do relator, o ministro Rodrigues Alckmin pediu vistas ao processo, adiando o restante do julgamento.

O julgamento prosseguiu em 06 de setembro, iniciando com o voto do ministro Rodrigues Alckmin, que acompanhou o voto de Baleeiro. Os demais ministros da primeira turma, Djaci Falcão e Oscar Corrêa Pina, também seguiram o posicionamento do relator, restando, portanto, provido em parte o recurso de Diógenes Sobrosa e negado o do Ministério Público Militar.

Em 03 de dezembro de 1974, o acórdão do Supremo Tribunal Federal transitou em julgado, ou seja, não poderiam mais haver recursos. Definitivamente, Ariston Lucena e Diógenes Sobrosa de Souza não estavam mais condenados à morte. Em setembro de 
que fora impossibilitado de realizar recurso ao STF. Assim, declarou-se extinta a sua punibilidade, e ele fora anistiado.

Ariston e Diógenes, porém, condenados a 30 anos de reclusão em processo transitado em julgado não poderiam ser anistiados em virtude do $\S 2^{\circ}$ do artigo $1^{\circ}$ da Lei de Anistia: " $\$ 2^{\circ}$ Excetuam-se dos benefícios da anistia os que foram condenados pela prática de crimes de terrorismo, assalto, sequestro e atentado pessoal”. Ambos conseguiram, porém, ainda em 1979, a sua liberdade condicional. O nome de Lucena apareceria novamente na ficha do DEOPS a respeito de sua mãe, Damaris, em seu último registro, datado de 25 de abril de 1980, a respeito do seu desembarque no aeroporto de Congonhas em voo procedente de Cuba, onde pôde se reencontrar com seu filho, Ariston, depois de 10 anos de separação.

\section{Considerações Finais}

O caso de Ariston Lucena e Diógenes Sobrosa de Souza é emblemático no que diz respeito à ditadura militar brasileira e à justiça militar. Membros de uma organização de resistência ao regime militar e companheiros de Lamarca em um foco de guerrilha, ambos acabam presos, torturados e julgados.

O processo de Ariston e Diógenes iniciou-se com um inquérito policial no qual foram obtidas informações e confissões mediante tortura, o que sequer foi escondido no decorrer do processo. Esse fato, porém, não representava um óbice no momento dos julgamentos, uma vez que essa informação sequer foi trazida à tona. As defesas, por sua vez, demonstram o caráter árduo do trabalho dos advogados que se dispunham a trabalhar em prol dos réus durante a ditadura. Sabedores de suas poucas chances de sucesso na defesa de seus clientes, os argumentos utilizados partiam para características pessoais dos réus, sua incapacidade de compreensão, seu caráter de meros peões em 
juiz auditor trabalhavam em conjunto buscando condenações que demonstrassem a sua competência como instrumentos da repressão. Assim, em um primeiro momento, Ariston e Diógenes acabam condenados à morte pelo assassinato do tenente Mendes Júnior durante sua fuga do Vale do Ribeira. Essa sentença só foi modificada em grau recursal e amenizada quando da análise pelo Supremo Tribunal Federal, uma corte composta por juízes civis.

Através do estudo realizado, foi possível verificar o caráter repressivo da legislação criada durante a ditadura militar com o objetivo de eliminar as pessoas tidas como subversivas. Os militares pretendiam, mediante documentos legais, dar um caráter de legalidade e legitimidade às suas ações contra os opositores do regime. O mesmo ocorria em relação aos tribunais militares. Sob a carapaça de uma instituição judicial em que ocorreriam julgamentos com oportunidade de defesa para os réus, escondia-se (mal) a sua real função: a eliminação de todos que fossem tidos como indesejáveis, seja através da prisão ou, como foi tentado, da pena de morte.

Apesar de existirem quatro casos de pessoas condenadas à morte por tribunais militares durante a ditadura militar brasileira, nenhuma das sentenças foi levada a cabo. Na realidade, os militares não necessitavam de uma sentença para cumprir os seus anseios. Outros Aristons e Diógenes não chegaram ao banco dos réus, sendo assassinados ou suicidados sem direito sequer a um julgamento de mentira. 


\section{Referências}

BRASIL. Superior Tribunal Militar. Processo n 146/70. Brasília, 1971. Disponível em: <http://bnmdigital.mpf.mp.br/pt-br/>. Acesso em: 28 fev. 2018.

CHAGAS, Fábio André Gonçalves das. A Vanguarda popular revolucionária: dilemas e perspectivas da luta armada no Brasil (1968-1971). 2000. Dissertação (Mestrado em História). UNESP - Faculdade de História, Direito e Serviço Social, -- Franca, 2000.

DEOPS. Ficha Damaris de Oliveira Lucena. 23 jul 1974. Disponível em: <http://www.arquivoestado.sp.gov.br/site/acervo/repositorio_digital/deops_ficha>. Acesso em 28 fev. 2018.

DEOPS. Ficha Diógenes Sobrosa de Souza. 26 out 1979. Disponível em: <http://www.arquivoestado.sp.gov.br/site/acervo/repositorio_digital/deops_ficha>. Acesso em 28 fev. 2018.

GASPARI, Elio. A ditadura escancarada. 2. ed. Rio de Janeiro: Intrínseca, 2014.

GORENDER, Jacob. Combate nas trevas: a esquerda brasileira: das ilusões perdidas à luta armada. São Paulo: Editora Ática, 1987.

JOSÉ, Emiliano; MIRANDA, Oldack. Lamarca, o capitão da guerrilha. São Paulo: Global Editora, 1980.

LEMOS, Renato. Poder Judiciário e poder militar (1964-1969). In: CASTRO, Celso; IZECKSOHN, Vitor; KRAAY, Hendrik (Orgs.). Nova história militar brasileira. Rio de Janeiro: Editora FGV / Bom Texto, 2004.

MACIEL, Wilma Antunes. $O$ capitão Lamarca e a VPR: a repressão judicial no Brasil. São Paulo: Alameda, 2006.

MARTINS FILHO, João Roberto. O palácio e a caserna: a dinâmica militar das crises políticas na ditadura (1964-1969). São Carlos: Ed. UFSCar, 1996.

MATTOS, Marco Aurélio Vannucchi Leme de. Em nome da segurança nacional: os processos da Justiça Militar contra a Ação Libertadora Nacional (ALN), 1969-1979. Dissertação (Mestrado em História), USP, 2002.

PAIVA, Marcelo Rubens. Polícia Militar conta a história pela metade. Folha de São Paulo. 16 jun. 1994. Disponível em:

<http://www1.folha.uol.com.br/fsp/1994/6/16/ilustrada/6.html>. Acesso em 19 jul. 2016. 
PEREIRA, Anthony W. Ditadura e repressão: o autoritarismo e o estado de direito no Brasil, no Chile e na Argentina. São Paulo: Paz e Terra, 2010.

SILVA, Angela Moreira Domingues da. Justiça e autoritarismo no Brasil: crime contra a segurança nacional e pena de morte durante a ditadura militar. Dimensões, v. 32, p. 111127, 2014,

SILVA, Angela Moreira Domingues da. Ditadura militar e repressão legal: a pena de morte rediviva e o caso Theodomiro Romeiro dos Santos (1969-1971). 2007. Disponível em: <https://cpdoc.fgv.br/sites/default/files/cfa21/angela_moreira_domingues_da_silva.pdf $>$. Acesso em 10 jun. 2016.

TELES, Janaína de Almeida. Em defesa da liberdade e da justiça: os advogados de perseguidos políticos de São Paulo nos anos 1970. Revista Brasileira de Ciências Criminais. v. 102. Maio de 2013. p. 287.

TELHADA, Paulo Adriano L. L. Quartel Luz: mansão da Rota: histórias do Batalhão "Tobias Aguiar”. São Paulo: Just Editora, 2011. 